\title{
Knowledge sharing and innovative work behavior: The case of Vietnam
}

\author{
Thi Phuong Linh Nguyen ${ }^{a^{*}}$, Ke Nghia Nguyen ${ }^{a}$, Thi Dong Doa and Thi Tuyet Mai Nguyena
}

${ }^{a}$ National Economics University, Vietnam

\begin{tabular}{|c|c|}
\hline CHRON I C LE & A B S T RACT \\
\hline $\begin{array}{l}\text { Article history: } \\
\text { Received April 14, } 2019 \\
\text { Received in revised format May } \\
\text { 10, } 2019 \\
\text { Accepted May } 102019 \\
\text { Available online } \\
\text { May } 112019 \\
\text { Keywords: } \\
\text { Knowledge sharing } \\
\text { Knowledge donation } \\
\text { Knowledge collection } \\
\text { Innovative work behavior }\end{array}$ & $\begin{array}{l}\text { Employees' knowledge sharing and innovative work behavior play an important role for the } \\
\text { development of Vietnam telecommunication enterprises. Knowledge sharing along with two } \\
\text { central processes; namely knowledge donation and collection, fosters employees' innovative } \\
\text { work behavior of Vietnam telecommunication enterprises. Based on a sample size survey of } \\
396 \text { Vietnam telecommunication employees and exploration factor analysis (EFA), } \\
\text { confirmatory factor analysis (CFA) and structural equation modeling (SEM), the study } \\
\text { determines factors such as trust, enjoyment in helping others, knowledge self-efficacy, } \\
\text { management support, using information and communication technology significantly influence } \\
\text { knowledge donation and collection. At the same time, knowledge donation and collection have } \\
\text { positive impacts on employees' innovative work behavior of Vietnam telecommunication } \\
\text { enterprises. Finally, several suggestions for enhancing employees' knowledge sharing and } \\
\text { innovative work behavior of Vietnam telecommunication enterprises managers are given. }\end{array}$ \\
\hline
\end{tabular}

(C) 2019 by the authors; licensee Growing Science, Canada.

\section{Introduction}

As the world is gradually moving towards a knowledge economy, knowledge is increasingly regarded as the main driving force of the economy. The success of future economies will be based on effective organizations absorbing, using and enhancing knowledge (Nassuora, 2011). However, most organizations tend to emphasize too many systems and tools rather than the core component of sharing knowledge among individuals. Knowledge sharing is valuable for organizations because through organizational knowledge sharing it is possible to improve efficiency, avoid waste, reduce training costs and risks. The study by Smith and Mckeen (2003) show that readiness to share knowledge is associated with profitability and productivity as well as labor costs. Besides, knowledge sharing is a factor that encourages individuals to create knowledge and convert it into greater power (Liebowitz \& Chen, 2001). Knowledge sharing with colleagues allows individuals to exchange and discuss ideas with peers, draw their attention to the benefits of ideas and implement ideas by turning into a viable solution (Mura et al., 2013). When employees actively share knowledge, knowledge is acquired and facilitates lawsuits that promote employees' innovative work behavior. In recent years, while Vietnam's telecommunications market has been saturated, many traditional services are at risk of decline, the spreading power of the industrial revolution 4.0 is getting faster and

* Corresponding author

E-mail address: linhnp@neu.edu.vn (T. P. L. Nguyen)

(C) 2019 by the authors; licensee Growing Science. doi: $10.5267 /$ j.uscm.2019.5.001 
stronger with rapid changes. Telecommunication is one of the fastest growing industries with the beginning of CDMA technology, followed by $2 \mathrm{G}$, then $3 \mathrm{G}, 4 \mathrm{G}$ and by 2018 was the era of $5 \mathrm{G}$ technology. In this context, Vietnam telecommunication enterprises, play the role of infrastructure for socio-economic development and need to promote innovation and develop technology to catch up and effectively exploit the great opportunities that this revolution brings. Most knowledge-sharing studies are concentrated in Western countries because the theory of knowledge sharing is mainly developed in those regions (Ma Prieto \& Pilar Pérez-Santana, 2014) and the studies of knowledge sharing in eastern countries have not been explored, significantly. Meanwhile, globalization creates a wide range of competition, knowledge sharing is therefore also meaningful for business organizations in developing countries (Burke, 2011). In particular, telecommunication is one of the service industries that requires a high level of knowledge sharing among employees (Akram et al., 2017) because this is a highly demanded industry for workers about knowledge, skills and experience. Understanding technical, programming, software, communication, system and other issues helps the employees of telecommunication enterprises develop in depth. Knowledge needs to be shared so that each individual can comprehend and apply to the work, thereby implementing the act of innovation to bring operational efficiency for the organization.

To fill this gap, this study develops a research model to link knowledge sharing enablers, processes and innovative work behavior. The study examines the influence of different factors including trust, enjoyment in helping others, knowledge self-efficacy, management support, using information and communication technology on knowledge sharing processes and whether these factors lead to innovative work behavior of Vietnam telecommunication enterprises employees. Based on a survey of 396 employees from 30 enterprises in Vietnam, the study applies structural equation modeling (SEM) to investigate the research model, to examine the hypotheses and to provide solutions for Vietnam telecommunication enterprises managers.

\section{Research model and hypotheses}

\subsection{Knowledge sharing}

Knowledge sharing involves different individuals at different levels in the organization; sharing between individuals or between individuals and a group of people. This process assumes that at least two parties are involved: one side conveys or distributes knowledge while the other side acquires and collects knowledge (Van den Hooff \& de Ridder, 2004; Vithessonthi, 2008). Weggeman (2000) and Van der Rijt (2002) also studied the difference between these two processes, in which: knowledge donation was shared with others and knowledge collection was to consult with colleagues to share their own intellectual capital. Van den Hooff and de Ridder (2004) defined knowledge sharing as the process by which individuals exchange knowledge (both tacit and explicit knowledge) together and create new knowledge together. Van den Hooff and de Ridder (2004) separated knowledge sharing into two processes of knowledge donation and collection when individuals exchange knowledge with each other. This view was inherited by Van den Hooff and de Ridder (2004) from the previous three studies of Weggeman (2000) that distinguished between donors and recipients in the process of knowledge sharing; Oldenkamp (2001) discussed how knowledge sharing relates to people with knowledge and recipients wish to learn knowledge; Ardichvili et al. (2003) with the view that knowledge sharing included the provision of new knowledge and the demand for new knowledge.

The factors that may affect these two processes are described in details as follows:

\section{Trust}

According to Homans (1958), social exchange theory suggests that individuals exchange resources through social exchange relationships. Social exchange is characterized by unspecified personal obligations, internal rewards and trust (Blau, 1964). According to Bandura (1989), social cognitive theory argued that individuals build and form trust before sharing their knowledge so without trust they will not share. Trust is defined as the extent to which an employee believes that knowledge sharing will benefit them and they will not be exploited by any party in the organization (Riege, 2005; Jones \& 
George, 1998). Trust in an organization improves connectivity between members and is seen as the center of all organizational relationships (Dyer \& Singh, 1998). Individuals feel encouraged to share knowledge when they find a trust in the relationship between recipients and sharers (Okyere-Kwakye et al., 2012). Ford and Chan (2003) argued that trust is one of the most important factors that promotes the process of sharing knowledge successfully. Huang et al. (2008) found that individuals in many cases and situations tend to hide the knowledge which they have if they are unsure of the outcome of sharing, so building trust at work is the first step to share knowledge, effectively. Therefore,

$\mathrm{H}_{1}$. Trust positively influences employee willingness to both (a) donate and (b) collect knowledge.

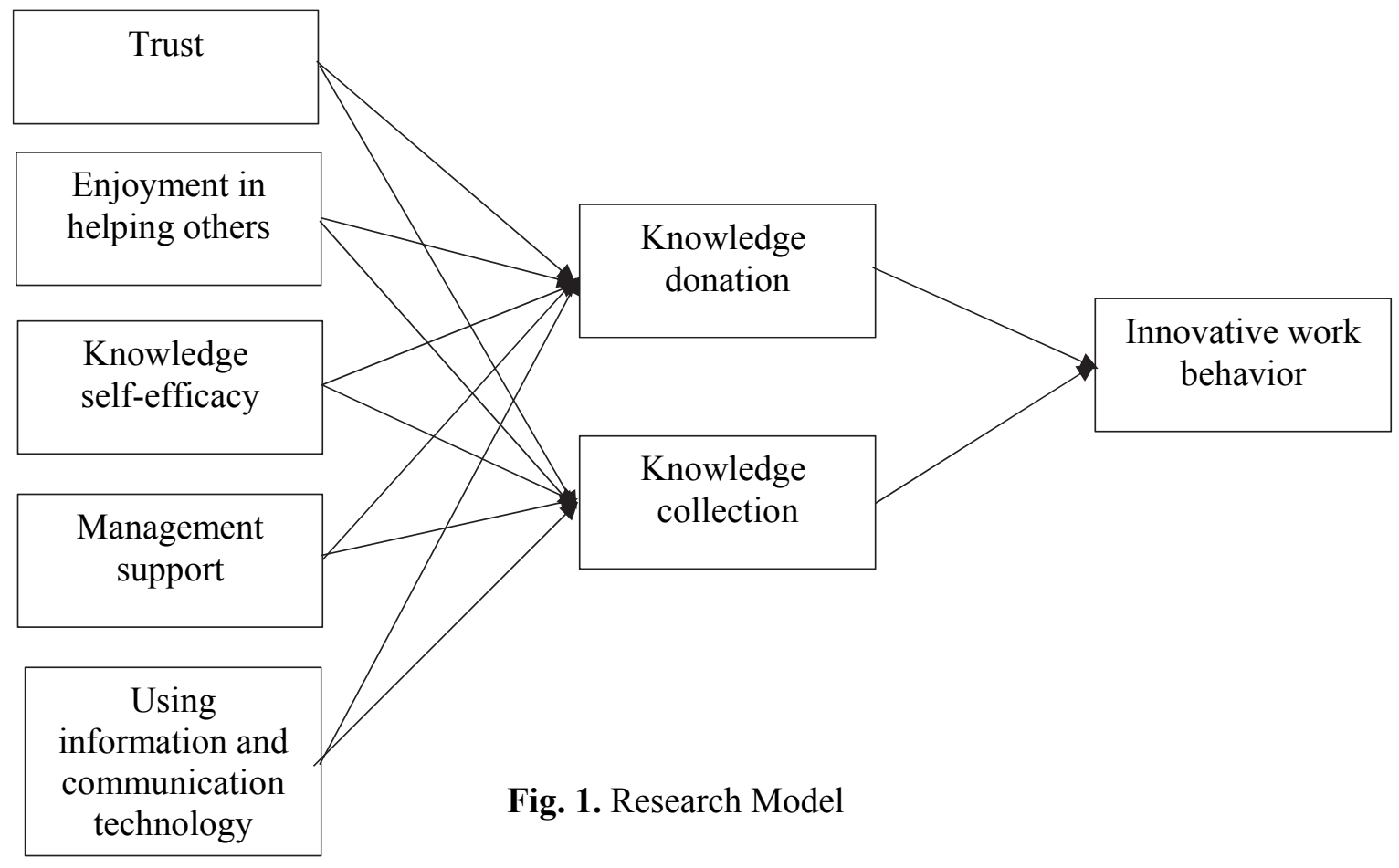

\section{Enjoyment in helping others}

Self-deterministic theory (Deci \& Ryan, 2008) determines each individual's intrinsic motivation derives from an individual's inner self and is not related to external pressure. The enjoyment in helping others is a form of autonomy determined by the sense of pleasure involved in an activity and doing that activity. Enjoyment in helping others is rooted in the concept of altruism, in contrast to selfishness, which is belief in impartial action and non-profit interest in the interests of others (Lin, 2007). Osterloh and Frey (2000) argued that knowledge sharing is motivated by the intrinsic motivations of the person sharing. Wasko and Faraj (2005) also demonstrated that individuals are intrinsically motivated to contribute knowledge because they like to help others. Altruism can promote an individual's sharing of knowledge with others without regard to the benefits received (Al-Qadhi et al., 2015). Therefore,

$\mathrm{H}_{2}$. Enjoyment in helping others positively influences employee willingness to both (a) donate and (b) collect knowledge.

\section{Knowledge self-efficacy}

Social cognitive theory (Bandura, 1997) argues that knowledge self-efficacy has an impact on the ability to organize certain behaviors so people can develop knowledge self-efficacy to exchange their knowledge during the cooperation. The theory of self-determination (Deci \& Ryan, 2008) describes the need for competence as a need to feel confident, know exactly what is done and be able to do it yourself. Self-knowledge is an individual's knowledge that can help solve work-related problems (Luthans, 
2002); therefore, it is a form of capacity that has been shown to influence knowledge sharing. When employees think their expertise can improve work efficiency and increase productivity, their attitude towards knowledge sharing will be changed and as a result they will be more inclined to share knowledge with others (Shin et al., 2007). Knowledge self-efficacy can encourage employees to share knowledge with others (Wasko \& Faraj, 2005). Many researchers have shown that the more confident employees are with their intellectual capital, the more willing they are to share knowledge to fulfill specific responsibilities (Constant et al., 1994). Self-control of knowledge makes work effective and helps to resolve work-related obstacles (Luthans, 2002). Therefore, some hypotheses are proposed as follows:

$\mathrm{H}_{3}$. Knowledge self-efficacy positively influences employee willingness to both (a) donate and (b) collect knowledge.

\section{Management support}

Self-determination theory (Deci \& Ryan, 2008) and motivation theory also determine the impact of external motivation on individual behavior and argue that external motivation stems from external pressure (Olatokun \& Nwafor, 2012). Therefore, external motivation to promote an act of sharing knowledge and external actors can be the management support, rewards, etc. The active participation in sharing knowledge of workers depends on the support of managers in the organization (Al-Qadhi et al., 2015). Management support is seen as an important factor influencing knowledge sharing among employees (Lee et al., 2006). Islam et al. (2014) emphasized the role of management support for knowledge sharing: leaders contribute to employees' learning from personal experience, persuade employees to transfer assigning knowledge to form new knowledge. Thus,

$\mathrm{H}_{4}$. Management support positively influences employee willingness to both (a) donate and (b) collect knowledge.

\section{Using information and communication technology}

The technology acceptance model (TAM) argues that the use of technology in regular activities, interactions and communication between individuals or members of a group or society affects behavior as sharing knowledge. By improving access to knowledge and eliminating obstacles in space and time between knowledge workers, information and communication technology (ICT) can improve the level of knowledge sharing (Hendriks, 1999). Information and communication technology and its ability to spread knowledge across different units of an organization can enable better comprehension in complex organizational environments (Coakes, 2006). Information technology is also seen as an indispensable tool to support the discovery of useful knowledge (Ho et al., 2012). Collaboration tools such as intranet systems allow people to work together and coordinate interaction. Each individual's knowledge, therefore, is transformed into organizational knowledge through the support of information technology (Zhao \& Luo, 2005). Teece (1998) shared that information and communication technologies reduce barriers to knowledge sharing. Therefore, it is important to identify relevant knowledge in different places of an organization to build a technical infrastructure to support and disseminate knowledge. Since then, the author proposes the following hypotheses:

$\mathrm{H}_{5}$. Using information and communication technology positively influences employee willingness to both (a) donate and (b) collect knowledge.

\subsection{Knowledge sharing and innovative work behavior}

Innovative work behavior is defined as the behavior of employees to create, introduce and apply new ideas intentionally at work, a group or an organization that contributes to performance (Janssen, 2000). This behavior is intentional behavior of individuals to create and implement new and useful ideas to benefit individuals, groups or organizations (Bos-Nehles, 2017). It is also a process for creating new problem-solving applications that begin with problem identification, finding and implementing 
organizational solutions (Turgut \& Beğenirbaş, 2013). Âmo and Kolvereid (2005) defined innovative work behavior as the ability to actively work to produce new products; find new markets, new processes and new combinations. The theory of knowledge creation relates to learn how knowledge is generated from individuals, organizations and environments (Nonaka \& Takeuchi, 1995). The creative theory of knowledge emphasizes interpersonal interaction to form new knowledge, which is the basis for the relationship between innovative work behavior and knowledge sharing. At the same time, previous researchers such as Radaelli et al. (2014), Akhavan et al. (2015), Jaberi (2016), Phung et al. (2017), Akram et al. (2018) affirmed in their studies the relationship between knowledge donation and collection with the act of innovation. Therefore, the hypotheses are proposed as follows:

$\mathrm{H}_{6}$. Knowledge donation and collection positively influence the employee's innovative work behavior.

\section{Research methodology}

\section{Data collection}

We conducted in-depth interviews with 10 employees of Vietnam telecommunication enterprises in the city of Hanoi, Da Nang, Ho Chi Minh to evaluate and adjust the questionnaire, and clarify the perceptions regarding two processes of knowledge sharing and innovative work behavior. The questions in the in-depth interview focused on the following issues: knowledge sharing conditions, knowledge sharing content, factors affecting the process of knowledge donation, factors affecting the process of knowledge collection and the relationship among knowledge donation, collection and innovative work behavior. The contents of the interview were recorded, stored and encrypted in the computer. The recording was then tape-taped, synthesized and analyzed to make conclusions to understand the similarities and differences between theoretical and practical models at Vietnam telecommunication enterprises. From the results of in-depth interviews, we identified the formal model for the study. A quantitative preliminary study with 25 employees was conducted to complete the questionnaire, to avoid errors and mislead the meaning of the observations, and to verify the reliability of the scales before conducting a formal investigation. Formal quantitative research was conducted through a survey with a sample of employees currently working in telecommunications enterprises in the North, Central and South of Vietnam, specifically the authors conducted a total of 30 telecommunications enterprises across the country, accounting for about $40 \%$ of the total number of telecommunications service providers currently doing business.

\section{Table 1}

Characteristics of the sample

\begin{tabular}{llcc}
\hline \multirow{2}{*}{ Gender } & Category & Number of respondent & Percentages (\%) \\
& Male & 243 & 61.4 \\
& Female & 153 & 38.6 \\
\hline \multirow{3}{*}{ Age } & Under 20 & 0 & 0.0 \\
& From 20 to 30 & 135 & 34.1 \\
& From 31 to 45 & 191 & 48.2 \\
& From 46 to 60 & 70 & 17.7 \\
\hline \multirow{3}{*}{ Education qualification } & Intermediate & 57 & 14.4 \\
& Bachelor & 254 & 64.1 \\
& Master or doctor & 85 & 21.5 \\
\hline \multirow{4}{*}{ Working experience } & Under 1 year & 33 & 8.3 \\
& From 1 to 5 years & 82 & 20.7 \\
& From 6 to 10 years & 183 & 46.2 \\
& From 11 to 15 years & 61 & 15.4 \\
& Over 15 years & 37 & 9.4 \\
\hline \multirow{2}{*}{ Working regions } & Hanoi (North) & 178 & 44.9 \\
& Da Nang (Central) & 87 & 22.0 \\
\hline
\end{tabular}


Their positions of employees in departments are much related to knowledge sharing such as: technology/information operations center, planning department, labor organization/human resources department, research and product development, technology department, quality management department, project management department and other functional departments. The authors investigated through questionnaires sent directly and via the Internet (email, social networks and forums) thanks to google docs tool. Time to collect data was July 2018. Statistics of 396 observations in the official quantitative research show that the sample of Vietnam telecommunication enterprises employees is mainly male (accounting for 61.4\%); most of them are in the age group from 31 to 45 (accounting for $48.2 \%$ ), and also belong to the age group from 20 to 30 (accounting for 34.1\%). In addition educational qualification of the surveyed employees has mainly graduated bachelor (accounting for 64.1\%); the number of employees with 6 to 10 years of work experience accounts for nearly half of the total number of observations, namely $46.2 \%$; followed by 1 to 5 years, accounting for $20.7 \%$. In addition, observations are still distributed more in the North, accounting for $44.9 \%$; then to the South, accounting for $33.1 \%$; finally to the Central, accounting for $22.0 \%$.

\section{Measures}

Scales were drawn from literature review and in-depth interviews. Observations and scales were used from foreign studies, which were translated from English into Vietnamese. After completing the translation, the authors consulted with some experts to ensure that the variables and scales were accurately and clearly translated and did not significantly change the meaning. At the same time, the authors added a new item for management support. All constructs were measured using multiple items. All items were measured using a five point Likert-type scale (ranging from $1=$ strongly disagree to $5=$ strongly agree). A list of items for each scale was presented in the appendix. The measurement approach for each theoretical construct in the model was described briefly below.

Trust depicting the trust of individuals about knowledge sharing will be beneficial and not exploited by any party in the organization was measured using five items derived from Seba et al. (2012). Enjoyment in helping others was measured using four items derived from Wasko and Faraj (2005), which focused on belief in the act of carefree and unprofessional interest in the interests of others. A five-item scale measuring knowledge self-efficacy was adapted from a measure developed by Bock et al. (2005). It shows the actions of individuals to realize their abilities to provide their knowledge to other individuals, groups and organizations. Management support was measured using five items adapted from studies by Tan and Zhao (2003) and a new item of the authors. These measurements are the vision of the organization related to managers' involvement in the effective use of knowledge. Additionally, using information technology and communication was measured based on six items taken from Xue et al. (2011), which referred to the degree of technological usability and capability regarding knowledge sharing. Knowledge donation was measured using four items adapted from an investigation by De Vries et al. (2006) which assessed the degree of employee willingness to contribute knowledge to colleagues. Knowledge collection was measured using four items derived from De Vries et al. (2006), which referred to consult with colleagues to share their own knowledge. Finally, innovative work behavior was measured using four items derived from Bysted (2013); Scott and Bruce (1994); Janssen (2000) which referred to the behavior of employees to create, introduce and apply new ideas intentionally at work, a group or an organization.

\section{Research results}

The reliability analysis was conducted to ascertain both consistency and stability. Cronbach's alpha is a reliability measurement that expresses how well the items in a set are positively correlated to each other. Previous studies have shown that items with a small itemtotal correlation (less than 0.3 ) will be excluded and criteria for scale selection when Cronbach's Alpha reliability is greater than 0.6. The larger the Cronbach's Alpha, the higher the internal consistency (Nunnally and Bernstein, 1994). Taken together, eight variables in the survey had Cronbach's Alpha ranged from 0.781 to 0.885 . All of these values were above 0.6 , generally considered to be the higher 
limit of reliability (Hair et al., 1995). However, 3 items (Tru5, Se5 and Ma4) were excluded from the study due to the correlation of item-total $<0.3$ (Hair et al., 2010). The appendix presents Cronbach's Alpha of indicators in the measurement model.

\section{Table 2}

KMO and Bartlett's Test

\begin{tabular}{lll}
\hline \multicolumn{2}{l}{ Kaiser-Meyer-Olkin Measure of Sampling Adequacy } & 0.772 \\
\hline \multirow{3}{*}{ Bartlett's Test of Sphericity } & Approx. Chi-Square & 10401.334 \\
& Df & 861 \\
& Sig. & 0.000 \\
\hline
\end{tabular}

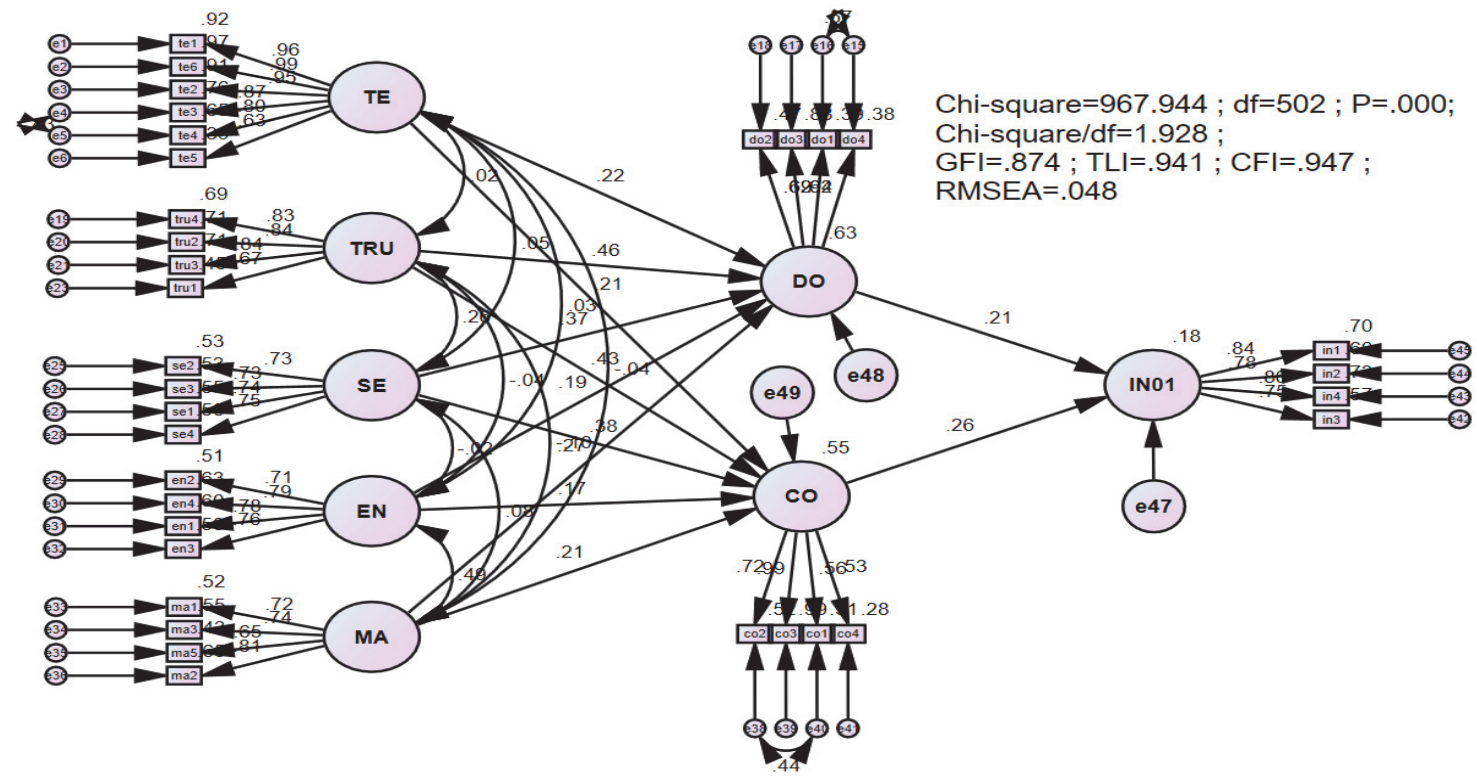

Fig. 2. Structural model analysis (SEM)

To confirm that this study data set is correct for factor analysis, the author assessed whether the KaiserMeyer-Olkin (KMO) measure of sampling adequacy value was 0.6 or above and determined that Sig. of Barlett's test of Sphericity value was significant (i.e.: 0.05 or less). As a result, all coefficients are relevant and significant in this study when $\mathrm{KMO}>0.6$ and sig. $=0$. To define how many factors to retain, a number of issues were considered. Using Kaiser's criterion, factors with an eigenvalue greater than one are suitable. In this phase, all eight components recorded eigenvalues above 1 . These eight components explain 73.476 percent of variance. Subsequently, all observations were included in the EFA analysis. Specific analysis results are described in the appendix. In verifying the scale, the CFA method in linear modeling (SEM) analysis has many advantages over conventional methods such as the coefficient-matching method, exploratory factor analysis (EFA). This method is characterized by allowing the author to examine the theoretical structure of the scales as well as the relationship between a research concept and other concepts without deviation from the measurement error (Steenkamp \& Van Trijp, 1991). Adequacy of the model is reflected in Chi-square (CMIN); Chi-square adjusted by degrees of freedom (CMIN/df); Comparative Fit Index - CFI; Tucker \& Lewis Index - TLI; Root Mean Square Error Approximation - RMSEA. The model is considered appropriate when the GFI, TLI, CFI values are $\geq 0.9$ (Bentler \& Bonnet, 1980); CMIN / df $\leq 2$; RMSEA $\leq 0.08$ (Steiger, 1990). Thọ and Trang (2008) suggested that the model received TLI, CFI $\geq 0.9$, CMIN / df $\leq 2$, RMSEA $\leq 0.08$, thus the model was considered appropriate for the data. The authors conducted factor analysis confirmed (CFA) to test the suitability of scale with the data collected. Results obtained in Fig 2: Chi-square/df $=$ 1.928; $\mathrm{GFI}=0.874 ; \mathrm{TLI}=0.941 ; \mathrm{CFI}=0.947$ and $\mathrm{RMSEA}=0.048$ (standardized estimate), showing 
scale models suitable for research data. Thus, with the data collected from the telecommunication enterprises employee survey, the research model and the relationship between the scales are accepted.

Table 3 shows the results of testing hypotheses with path coefficient derived from structural equation modeling (SEM). Therefore, all hypotheses are accepted because of statistical significance.

Table 3

Unstandardized Regression Weights

\begin{tabular}{|c|c|c|c|c|c|c|c|}
\hline & & & Estimate & S.E. & C.R. & $\mathrm{P}$ & Conclusion \\
\hline DO & $\leftarrow$ & TE & 0.178 & 0.031 & 5.797 & $* * *$ & Statistical significance \\
\hline DO & $\leftarrow$ & TRU & 0.505 & 0.049 & 10.212 & $* * *$ & Statistical significance \\
\hline DO & $\leftarrow$ & SE & 0.419 & 0.054 & 7.723 & $* * *$ & Statistical significance \\
\hline DO & $\leftarrow$ & EN & 0.223 & 0.059 & 3.768 & $* * *$ & Statistical significance \\
\hline DO & $\leftarrow$ & MA & 0.361 & 0.070 & 5.183 & $* * *$ & Statistical significance \\
\hline $\mathrm{CO}$ & $\leftarrow$ & MA & 0.294 & 0.070 & 4.194 & $* * *$ & Statistical significance \\
\hline $\mathrm{CO}$ & $\leftarrow$ & EN & 0.209 & 0.060 & 3.482 & $* * *$ & Statistical significance \\
\hline $\mathrm{CO}$ & $\leftarrow$ & SE & 0.456 & 0.056 & 8.195 & $* * *$ & Statistical significance \\
\hline $\mathrm{CO}$ & $\leftarrow$ & TRU & 0.492 & 0.050 & 9.886 & $* * *$ & Statistical significance \\
\hline $\mathrm{CO}$ & $\leftarrow$ & $\mathrm{TE}$ & 0.177 & 0.031 & 5.667 & $* * *$ & Statistical significance \\
\hline IN01 & $\leftarrow$ & DO & 0.201 & 0.066 & 3.068 & 0.002 & Statistical significance \\
\hline IN01 & $\leftarrow$ & $\mathrm{CO}$ & 0.245 & 0.061 & 4.009 & $* * *$ & Statistical significance \\
\hline
\end{tabular}

Unstandardized Regression Weights (Table 3) shows that the factors affect the two processes of knowledge donation and collection have P-value less than 0.05. Regression weights positive signs also reflect these factors have a positive impact on knowledge donation and collection. At the same time, the influence of knowledge donation and collection to the behavior of innovation is also statistically significant in this study.

Table 4

Regression Weights

\begin{tabular}{|c|c|c|c|c|c|c|c|}
\hline & & & timate & & & & Estimate \\
\hline DO & $\leftarrow$ & $\mathrm{TE}$ & 0.222 & $\mathrm{CO}$ & $\leftarrow$ & EN & 0.168 \\
\hline DO & $\leftarrow$ & TRU & 0.457 & $\mathrm{CO}$ & $\leftarrow$ & $\mathrm{SE}$ & 0.379 \\
\hline DO & $\leftarrow$ & SE & 0.366 & $\mathrm{CO}$ & $\leftarrow$ & TRU & 0.425 \\
\hline DO & $\leftarrow$ & EN & 0.188 & $\mathrm{CO}$ & $\leftarrow$ & TE & 0.210 \\
\hline DO & $\leftarrow$ & MA & 0.268 & IN01 & $\leftarrow$ & DO & 0.206 \\
\hline $\mathrm{CO}$ & $\leftarrow$ & MA & 0.208 & IN01 & $\leftarrow$ & $\mathrm{CO}$ & 0.264 \\
\hline
\end{tabular}

The standardized weight values of standardized weight tables also have positive values reflecting the positive impact of the factors on the processes of knowledge donation and collection and these two processes with innovative work behavior. The impact level is expressed through the magnitude of the standardized weights. For the scale of knowledge donation, trust and knowledge self-efficacy are the most influential factors in the process of knowledge donation with standardized weights of 0.457 and 0.366 respectively. For the scale of knowledge collection, trust and knowledge self-efficacy are still the most influential factors in the process of knowledge collection with standardized weights of 0.425 and 0.379 respectively. In the relationship between knowledge donation and collection with innovative work behavior, knowledge collection has a stronger impact on innovative work behavior with standardized weights of 0.206 and 0.264 respectively.

\section{Discussion and Implications}

This research approached both theoretical and practical perspectives. Theoretically, this research showed a research model for empirical studies to explore factors affecting two knowledge sharing processes and the relationship between two knowledge sharing processes and innovative work behavior. The results from a structural equation modeling (SEM) approach have given significant supports for all hypothesized relations. The results have shown that five factors, namely trust, 
enjoyment in helping others, knowledge self-efficacy, management support, using information and communication technology significantly influence knowledge donation and collection processes. The results have also indicated that employees' willingness to donate and collect knowledge enable themselves to improve innovative work behavior. From a practical perspective, some suggestions may be provided about how enterprises can promote knowledge sharing process to improve employees' innovative work behavior. Discussion of the findings, implications for managers are described below.

\section{Discuss research findings}

The main purpose of this study was to determine the relationship between factors related to knowledge sharing processes and between knowledge sharing processes and innovative work behavior. After testing the hypotheses, some conclusions are as follows:

(i) Trust is positively correlated with knowledge donation and collection. This conclusion is consistent with the results of many studies (Davenport \& Prusak, 1998; Costa et al., 2001; Zárraga \& Bonache, 2003; Currie \& Kerrin, 2003; Wu et al., 2009; Ismail \& Yusof, 2010; Lee et al., 2010; Wickramasinghe \& Widyaratne, 2012; Rusly et al., 2014; Al-Qadhi et al., 2015; Binsawad et al., 2017). Trust will not be exploited, trust in the honesty, responsibility and trust of colleagues when sharing knowledge will help telecommunication enterprises employees actively communicate and acquire knowledge. They will share the know-how and skills they have with their colleagues when they believe that their colleagues will not use the same know-how to confront them or show their intimacy just to get their share. Many employees desire to acquire knowledge but they only feel assured if their colleagues are honest and trustworthy when sharing knowledge. In this study, trust is the most influential factor in both knowledge donation and collection, thus to enhance knowledge sharing, managers need to have solutions to influence each employees' trust.

(ii) Enjoyment in helping others is positively correlated with knowledge donation and collection. Many authors also agree with this observation (Kanaan \& Gharibeh, 2013; Sliat \& Alnsour, 2013; Binsawad et al., 2017; Phung et al., 2017; Podrug et al., 2017). In addition, Lin (2007) also concluded enjoyment in helping others affect both the processes of knowledge donation and collection. Sharing knowledge or not sharing knowledge depends on the personality and emotional state of each telecommunication enterprise employee. Knowledge is personal property so when they are interested in sharing, feeling comfortable when sharing, they will be ready to convey their knowledge to their colleagues and also be willing to receive knowledge from colleagues.

(iii) Knowledge self-efficacy is positively correlated with knowledge donation and collection. Studies conclude the relationship between knowledge self-efficacy and knowledge sharing by Constant et al. (1994), Kankanhalli et al. (2005), Zhang and Fai Ng (2012), Binsawad et al. ( 2017) and Phung et al. (2017). In particular, Lin (2007) also affirmed the relationship between knowledge self-efficacy and the two central processes of knowledge sharing: knowledge donation and collection. When employees themselves have awareness that sharing their knowledge will help their colleagues solve their problems, help them work together to create new business opportunities for the organization, they will actively communicate and acquire knowledge. The analysis of linear structure (SEM) leads to the conclusion that telecommunication enterprises employees want to share knowledge, but in fact, whether they communicate and acquire knowledge depends largely on knowledge self-efficacy. Therefore, managers need to have solutions to increase knowledge self-efficacy for employees to promote knowledge sharing in Vietnamese telecommunications enterprises.

(iv) Management support is positively correlated with knowledge donation and collection. Many authors in the world also agree with this observation such as Han and Anantatmula (2007), Kanaan et al. (2013), Sliat and Alnsour (2013), Al-Qadhi et al. (2015), Binsawad et al. (2017), Podrug et al. (2017), even Lin (2007) also concluded that management support affects two central processes of 
knowledge sharing: knowledge donation and collection. Al-Qadhi et al. (2015) affirmed that managers should support employees in all aspects. Thus, the view of the benefits of sharing knowledge, encouragement as well as helping and facilitating the knowledge sharing, managers will promote employees to enhance communication and acquire knowledge. In particular, an item was added to the scale of management support by the author "I was acknowledged by the manager when sharing knowledge and ideas with colleagues" in accordance with the research model. Employees feel motivated to share knowledge when they feel support and recognition from their managers for their behavior.

(v) Using information and communication technology is positively correlated with knowledge donation and collection. This conclusion coincides with the conclusions in many studies, including studies by Han and Anantatmula (2007), Zawawi et al. (2011), Kanaan et al. (2013), Binsawad et al. (2017), Podrug et al. (2017). By the method of linear structural analysis (SEM) with the observation sample as telecommunications enterprise employees in Vietnam, the authors assert that the use of information and communication technology really supports the knowledge sharing among employees.

(vi) Knowledge donation and collection are positively correlated with innovative work behavior. This relationship can be also mentioned by Radaelli et al. (2014), Akhavan et al. (2015), Jaberi (2016), Phung et al. (2017), Akram et al. (2018).

\section{Implication for managers}

Based on the results of formal quantitative research, trust and knowledge self-efficacy have the strongest impact on the two central processes of knowledge sharing: knowledge donation and collection. Some suggestions for telecommunications enterprises managers are given as follows:

For trust factors: building an open and comfortable working environment based on mutual trust and consensus; strengthening collective activities, exchanging between employees, between departments; building a teamwork model for each project; training awareness for employees about teamwork spirit, mutual support in work. For knowledge self-efficacy: giving compliments to employees who contribute their ideas; designing a software system that recognizes employee contributions to collective work and regularly evaluates the effectiveness of those contributions to the organization's performance; promoting training or building a learning organization to improve qualifications and expertise for employees; designing or buying software that includes tests to examine professional knowledge related to employees' work. The results of qualitative and quantitative research show that knowledge sharing consists of two central processes of knowledge donation and collection that are related to individuals' innovative work behaviors. Therefore, managers need to make proposals to enhance knowledge sharing to impact on innovative work behavior.

The results of interviews with telecommunication enterprises employees showed that some answers directly addressed the behavior of innovation such as:

An employee with 6 - 10 years of experience answered: "If there is no measure, employees like me always want to do it the old way, do not want to change or improve at work. In the business I am doing a lot when it is difficult to give my opinion to senior leaders, so I think there must be appropriate measures to change our way of thinking and how we have been doing for years".

A manager with more than 15 years of experience answered: "I often use brainstorming methods for employees to think and give ideas and suggestions at work. The important thing is how to apply the ideas and suggestions of the employees, who will be the ones who do it because if not applied, all ideas and suggestions will only be on paper forever".

Therefore, the authors propose a number of suggestions for telecommunication enterprises managers to influence the behavior of innovation of employees:

Firstly, applying Kaizen method in management. Managers encourage employees to come up with new ideas and suggestions through suggestion boxes, software systems, social networks, etc., then evaluating and choosing new ideas with feasible proposals to apply. Kaizen method could be 
successfully implemented only when both Vietnamese executives and managers have innovative and modern thinking ideas. Secondly, organizing seminars periodically with the participation of managers and employees in each department. At the seminar, each employee must comment on his/her current work and discuss plans, development strategies, work processes, new products/ services. After the seminar, feasible ideas will be assigned to the proponent and some colleagues to implement. Thirdly, taking the time and resources to test and implement new ideas. The work of Vietnamese telecom enterprise employees mostly has to run according to the set plan and schedule, so in many cases they are forced to use traditional methods to deploy. New ideas when applied are not always successful right from the first time, so managers need to build plans, assign tasks and spend time testing.

\section{Acknowledgement}

This research is funded by National Economics University, Hanoi, Vietnam.

\section{References}

Akhavan, P., Hosseini, S. M., Abbasi, M., \& Manteghi, M. (2015). Knowledge-sharing determinants, behaviors, and innovative work behaviors: an integrated theoretical view and empirical examination. Aslib Journal of Information Management, 67(5), 562-591.

Akram, T., Lei, S., Haider, M. J., \& Hussain, S. T. (2018). Exploring the impact of knowledge sharing on the innovative work behavior of employees: A study in China. International Business Research, 11(3), 186-194.

Akram, T., Lei, S., Haider, M. J., Hussain, S. T., \& Puig, L. C. M. (2017). The effect of organizational justice on knowledge sharing: Empirical evidence from the Chinese telecommunications sector. Journal of Innovation \& Knowledge, 2(3), 134-145.

Al-Qadhi, Y. H., Md Nor, K., Ologbo, A. C., \& Knight, M. B. (2015). Knowledge sharing in a multinationality workforce: Examining the factors that influence knowledge sharing among employees of diverse nationalities. Human Systems Management, 34(3), 149-165.

Åmo, B. W., \& Kolvereid, L. (2005). Organizational strategy, individual personality and innovation behavior. Journal of Enterprising Culture, 13(01), 7-19.

Ardichvili, A., Page, V., \& Wentling, T. (2003). Motivation and barriers to participation in virtual knowledge-sharing communities of practice. Journal of Knowledge Management, 7(1), 64-77.

Bandura, A. (1989). Regulation of cognitive processes through perceived self-efficacy. Developmental Psychology, 25(5), 729.

Bentler, P. M., \& Bonett, D. G. (1980). Significance tests and goodness of fit in the analysis of covariance structures. Psychological Bulletin, 88(3), 588.

Binsawad, M., Sohaib, O., \& Hawryszkiewycz, I. (2017). Knowledge-Sharing in Technology Business Incubator.

Blau, P. M. (1964). Exchange and power in social life. New Brunswick.

Bock, G. W., Zmud, R. W., Kim, Y. G., \& Lee, J. N. (2005). Behavioral intention formation in knowledge sharing: Examining the roles of extrinsic motivators, social-psychological factors, and organizational climate. MIS Quarterly, 29(1), 87-111.

Bos-Nehles, A., Renkema, M., \& Janssen, M. (2017). HRM and innovative work behaviour: A systematic literature review. Personnel Review, 46(7), 1228-1253.

Burke, M. E. (2011). Knowledge sharing in emerging economies. Library Review, 60(1), 5-14.

Bysted, R. (2013). Innovative employee behaviour: the moderating effects of mental involvement and job satisfaction on contextual variables. European Journal of Innovation Management, 16(3), 268284.

Coakes, E. (2006). Storing and sharing knowledge: Supporting the management of knowledge made explicit in transnational organizations. The Learning Organization, 13(6), 579-593.

Constant, D., Kiesler, S., \& Sproull, L. (1994). What's mine is ours, or is it? A study of attitudes about information sharing. Information Systems Research, 5(4), 400-421. 
Costa, A. C., Roe, R. A., \& Taillieu, T. (2001). Trust within teams: The relation with performance effectiveness. European Journal of Work and Organizational Psychology, 10(3), 225-244.

Currie, G., \& Kerrin, M. (2003). Human resource management and knowledge management: enhancing knowledge sharing in a pharmaceutical company. The International Journal of Human Resource Management, 14(6), 1027-1045.

Davenport, T. H., \& Prusak, L. (1998). Working knowledge: How organizations manage what they know. Harvard Business Press.

De Vries, R. E., Van den Hooff, B., \& de Ridder, J. A. (2006). Explaining knowledge sharing: The role of team communication styles, job satisfaction, and performance beliefs. Communication Research, 33(2), 115-135.

Deci, E. L., \& Ryan, R. M. (2008). Self-determination theory: A macrotheory of human motivation, development, and health. Canadian psychology/Psychologie canadienne, 49(3), 182.

Dyer, J. H., \& Singh, H. (1998). The relational view: Cooperative strategy and sources of interorganizational competitive advantage. Academy of Management Review, 23(4), 660-679.

Ford, D. P., \& Chan, Y. E. (2003). Knowledge sharing in a multi-cultural setting: a case study. Knowledge Management Research \& Practice, 1(1), 11-27.

Hair, J. F., Anderson, R. E., Babin, B. J., \& Black, W. C. (2010). Multivariate data analysis: A global perspective (Vol. 7).

Han, B. M., \& Anantatmula, V. S. (2007). Knowledge sharing in large IT organizations: a case study. Vine, 37(4), 421-439.

Hendriks, P. (1999). Why share knowledge? The influence of ICT on the motivation for knowledge sharing. Knowledge and Process Management, 6(2), 91-100.

Ho, L. A., Kuo, T. H., \& Lin, B. (2012). How social identification and trust influence organizational online knowledge sharing. Internet Research, 22(1), 4-28.

Homans, G. C. (1958). Social behavior as exchange. American Journal of Sociology, 63(6), 597-606.

Huang, Q., Davison, R. M., \& Gu, J. (2008). Impact of personal and cultural factors on knowledge sharing in China. Asia Pacific Journal of Management, 25(3), 451-471.

Islam, S., Zeisel, A., Joost, S., La Manno, G., Zajac, P., Kasper, M., ... \& Linnarsson, S. (2014). Quantitative single-cell RNA-seq with unique molecular identifiers. Nature Methods, 11(2), 163.

Ismail, M. B., \& Yusof, Z. M. (2010). The impact of individual factors on knowledge sharing quality. Journal of Organizational Knowledge Management, 13, 1-12

Jaberi, E. (2016). The effect of knowledge sharing on innovative behavior among employee of Besat hospital in city of Hamedan. International Academic Journal of Accounting and Financial Management, 3(4), 41-47.

Janssen, O. (2000). Job demands, perceptions of effort-reward fairness and innovative work behaviour. Journal of Occupational and Organizational Psychology, 73(3), 287-302.

Jones, P., \& Jordan, J. (1998). Knowledge orientations and team effectiveness. International Journal of Technology Management, 16(1-3), 152-161.

Kanaan, R., \& Gharibeh, A. A. H. (2013). The impact of knowledge sharing enablers on knowledge sharing capability: An empirical study on Jordanian telecommunication firms. European Scientific Journal, ESJ, 9(22).

Kankanhalli, A., Tan, B. C., \& Wei, K. K. (2005). Contributing knowledge to electronic knowledge repositories: An empirical investigation. MIS quarterly, 29(1).

Lee, M. K., Cheung, C. M., Lim, K. H., \& Ling Sia, C. (2006). Understanding customer knowledge sharing in web-based discussion boards: An exploratory study. Internet Research, 16(3), 289-303.

Lee, P., Gillespie, N., Mann, L., \& Wearing, A. (2010). Leadership and trust: Their effect on knowledge sharing and team performance. Management learning, 41(4), 473-491.

Liebowitz, J., \& Yan, C. (2004). Knowledge sharing proficiencies: the key to knowledge management. In Handbook on Knowledge Management 1 (pp. 409-424). Springer, Berlin, Heidelberg.

Lin, H. F. (2007). Effects of extrinsic and intrinsic motivation on employee knowledge sharing intentions. Journal of Information Science, 33(2), 135-149.

Luthans, F. (2002). Positive organizational behavior: Developing and managing psychological strengths. Academy of Management Perspectives, 16(1), 57-72. 
Ma Prieto, I., \& Pilar Pérez-Santana, M. (2014). Managing innovative work behavior: the role of human resource practices. Personnel Review, 43(2), 184-208.

Mura, M., Lettieri, E., Radaelli, G., \& Spiller, N. (2013). Promoting professionals' innovative behaviour through knowledge sharing: the moderating role of social capital. Journal of Knowledge Management, 17(4), 527-544.

Nassuora, A. B. (2011). Knowledge sharing in institutions of higher learning. American Academic \& Scholarly Research Journal, 1(1), 29-34.

Nonaka, I., \& Takeuchi, H. (1995). The knowledge-creating company: How Japanese companies create the dynamics of innovation. Oxford university press.

Nunnally, J. C., \& Bernstein, I. H. (1994). Psychological theory. New York, NY: MacGraw-Hill, 131147.

Okyere-Kwakye, E., Nor, K. M., \& Ologbo, A. (2012). Factors that impel individuals' to share knowledge. In Knowledge Management International Conference (KMICe) (Vol. 2012, pp. 4-6).

Olatokun, W., \& Nwafor, C. I. (2012). The effect of extrinsic and intrinsic motivation on knowledge sharing intentions of civil servants in Ebonyi State, Nigeria. Information Development, 28(3), 216234.

Oldenkamp, J. H. (2001, November). Limitations of managing knowledge sharing. In Proceedings of the Second European Conference on Knowledge Management, Bled, Slovenia (pp. 411-418).

Osterloh, M., \& Frey, B. S. (2000). Motivation, knowledge transfer, and organizational forms. Organization science, 11(5), 538-550.

Phung, V. D., Hawryszkiewycz, I., Chandran, D., \& Ha, B. M. (2017, December). Knowledge sharing and innovative work behaviour: A case study from Vietnam. In Australasian Conference on Information Systems.

Podrug, N., Filipović, D., \& Kovač, M. (2017). Knowledge sharing and firm innovation capability in Croatian ICT companies. International Journal of Manpower, 38(4), 632-644.

Radaelli, G., Lettieri, E., Mura, M., \& Spiller, N. (2014). Knowledge sharing and innovative work behaviour in healthcare: A micro-level investigation of direct and indirect effects. Creativity and Innovation Management, 23(4), 400-414.

Riege, A. (2005). Three-dozen knowledge-sharing barriers managers must consider. Journal of Knowledge Management, 9(3), 18-35.

Rusly, F., Yih-Tong Sun, P., \& L. Corner, J. (2014). The impact of change readiness on the knowledge sharing process for professional service firms. Journal of Knowledge Management, 18(4), 687-709.

Scott, S. G., \& Bruce, R. A. (1994). Determinants of innovative behavior: A path model of individual innovation in the workplace. Academy of Management Journal, 37(3), 580-607.

Seba, I., Rowley, J., \& Lambert, S. (2012). Factors affecting attitudes and intentions towards knowledge sharing in the Dubai Police Force. International Journal of Information Management, 32(4), 372380.

Shin, S. K., Ishman, M., \& Sanders, G. L. (2007). An empirical investigation of socio-cultural factors of information sharing in China. Information \& Management, 44(2), 165-174.

Sliat, R. K., \& Alnsour, M. S. (2013). Business Innovation through knowledge sharing: An applied study on the Jordanian Mobile Telecommunications Sector. European Journal of Business and Management, 5(18), 8-17.

Smith, H. A., \& McKeen, J. D. (2003). Instilling a knowledge-sharing culture. Queen's Centre for Knowledge-Based Enterprises, 20(1), 1-17.

Steenkamp, J. B. E., \& Van Trijp, H. C. (1991). The use of LISREL in validating marketing constructs. International Journal of Research in Marketing, 8(4), 283-299.

Steiger, J. H. (1990). Structural model evaluation and modification: An interval estimation approach. Multivariate Behavioral Research, 25(2), 173-180.

Tan, H. H., \& Zhao, B. (2003). Individual-and perceived contextual-level antecedents of individual technical information inquiry in organizations. The Journal of Psychology, 137(6), 597-621.

Teece, D. J. (1998). Capturing value from knowledge assets: The new economy, markets for knowhow, and intangible assets. California Management Review, 40(3), 55-79. 
Thọ, N. Đ., \& Trang, N. T. M. (2008). Nghiên cứu khoa học Marketing-Úng dụng mô hình cấu trúc tuyến tính SEM. NXB Đại học quốc gia thành phố Hồ Chí Minh.

Turgut, E., \& Beğenirbaş, M. (2013). Çalışanların yenilikçi davranışları üzerinde sosyal sermaye ve yenilikçi iklimin rolü: Sağlık sektöründe bir araştırma. Kara Harp Okulu Bilim Dergisi, 23(2), 101124.

Van Den Hooff, B., \& De Ridder, J. A. (2004). Knowledge sharing in context: the influence of organizational commitment, communication climate and CMC use on knowledge sharing. Journal of Knowledge Management, 8(6), 117-130.

Van der Rijt, P. G. A. (2002). Precious Knowledge. Amsterdam: The Amsterdam School of Communications Research.

Vithessonthi, C. (2008). Social interaction and knowledge sharing behaviors in multinational corporations. The Business Review, 10(2), 324-331.

Xue, Y., Bradley, J., \& Liang, H. (2011). Team climate, empowering leadership, and knowledge sharing. Journal of Knowledge Management, 15(2), 299-312.

Wasko, M. M., \& Faraj, S. (2005). Why should I share? Examining social capital and knowledge contribution in electronic networks of practice. MIS Quarterly, 29(1), 35-57.

Weggeman, M. C. D. P. (2000). Kennismanagement: de praktijk. Scriptum Management.

Wickramasinghe, V., \& Widyaratne, R. (2012). Effects of interpersonal trust, team leader support, rewards, and knowledge sharing mechanisms on knowledge sharing in project teams. Vine, 42(2), 214-236.

Wu, W. L., Lin, C. H., Hsu, B. F., \& Yeh, R. S. (2009). Interpersonal trust and knowledge sharing: Moderating effects of individual altruism and a social interaction environment. Social Behavior and Personality: An International Journal, 37(1), 83-93.

Zárraga, C., \& Bonache, J. (2003). Assessing the team environment for knowledge sharing: an empirical analysis. International Journal of Human Resource Management, 14(7), 1227-1245.

Zawawi, A. A., Zakaria, Z., Kamarunzaman, N. Z., Noordin, N., Sawal, M. Z. H. M., Junos, N. M., \& Najid, N. S. A. (2011). The study of barrier factors in knowledge sharing: A case study in public university. Management Science and Engineering, 5(1), 59.

Zhao, H., \& Luo, Y. (2005). Antecedents of knowledge sharing with peer subsidiaries in other countries: A perspective from subsidiary managers in a foreign emerging market. Management International Review, 45(1), 71.

Zhang, P., \& Fai Ng, F. (2012). Attitude toward knowledge sharing in construction teams. Industrial Management \& Data Systems, 112(9), 1326-1347. 


\section{Appendix 1}

\begin{tabular}{|c|c|c|}
\hline Factors & Symbols & Items \\
\hline \multirow{5}{*}{ Trust (Tru) } & Tru1 & $\begin{array}{l}\text { My colleagues will not take advantage of me on the knowledge that I share with } \\
\text { them. }\end{array}$ \\
\hline & Tru2 & I am sure that the knowledge I share with my colleagues will not be manipulated. \\
\hline & Tru3 & My colleagues are truthful in sharing knowledge with me. \\
\hline & Tru4 & My colleagues are responsible and dependable in sharing knowledge with me. \\
\hline & Tru5 & $\begin{array}{l}\text { I believe that my colleagues will not use the knowledge I share with them against } \\
\text { me. }\end{array}$ \\
\hline \multirow{4}{*}{$\begin{array}{l}\text { Enjoyment in } \\
\text { helping others (En) }\end{array}$} & En1 & I enjoy sharing my knowledge with colleagues \\
\hline & En2 & I enjoy helping colleagues by sharing my knowledge \\
\hline & En3 & It feels good to help someone by sharing my knowledge \\
\hline & En4 & Sharing my knowledge with colleagues is pleasurable \\
\hline \multirow{5}{*}{$\begin{array}{l}\text { Knowledge self- } \\
\text { efficacy (Se) }\end{array}$} & Se1 & $\begin{array}{l}\text { My knowledge sharing would help other members in the organization to solve } \\
\text { their problems }\end{array}$ \\
\hline & $\mathrm{Se} 2$ & $\begin{array}{l}\text { My knowledge sharing would create new business opportunities for the } \\
\text { organization }\end{array}$ \\
\hline & $\mathrm{Se} 3$ & My knowledge sharing would improve work process in the organization \\
\hline & $\mathrm{Se} 4$ & My knowledge sharing would increase productively in the organization \\
\hline & $\operatorname{Se} 5$ & $\begin{array}{l}\text { My knowledge sharing would help the organization achieve its performance } \\
\text { objectives }\end{array}$ \\
\hline \multirow{5}{*}{$\begin{array}{l}\text { Management support } \\
\text { (Ma) }\end{array}$} & Ma1 & Managers think that encouraging knowledge sharing with colleagues is beneficial \\
\hline & Ma2 & $\begin{array}{l}\text { Managers always support and encourage employees to share their knowledge with } \\
\text { colleagues }\end{array}$ \\
\hline & Ma3 & $\begin{array}{l}\text { Managers provide most of the necessary help and resources to enable employees } \\
\text { to share knowledge }\end{array}$ \\
\hline & $\mathrm{Ma} 4$ & $\begin{array}{l}\text { Managers are keen to see that the employees are happy to share their knowledge } \\
\text { with colleagues }\end{array}$ \\
\hline & Ma5 & $\begin{array}{l}\text { I was acknowledged by the manager when sharing knowledge and ideas with } \\
\text { colleagues }\end{array}$ \\
\hline \multirow{6}{*}{$\begin{array}{l}\text { Using information } \\
\text { and communication } \\
\text { technology }(\mathrm{Te})\end{array}$} & Te1 & $\begin{array}{l}\text { Our organization introduces new technology platforms that enable knowledge } \\
\text { sharing for more effective operations }\end{array}$ \\
\hline & $\mathrm{Te} 2$ & $\begin{array}{l}\text { Our organization has expertise in the usage and maintenance of critical } \\
\text { information infrastructure, e.g. intranet, extranet, groupware }\end{array}$ \\
\hline & $\mathrm{Te} 3$ & $\begin{array}{l}\text { Our information systems infrastructure is updated regularly to facilitate effective } \\
\text { knowledge sharing and creation }\end{array}$ \\
\hline & Te4 & $\begin{array}{l}\text { Social network systems enable the search and sharing of ideas and information } \\
\text { within the organization and with our stakeholders }\end{array}$ \\
\hline & Te5 & Our groupware systems enable knowledge sharing among employees \\
\hline & Te6 & Our intranet systems enable the sharing of ideas and critical documents \\
\hline \multirow{4}{*}{$\begin{array}{l}\text { Knowledge donation } \\
\text { (Do) }\end{array}$} & Do1 & When I learn something new, I tell my colleagues about it \\
\hline & Do2 & I share the knowledge I have, with my colleagues \\
\hline & Do3 & I think it is important that my colleagues know what I am doing \\
\hline & Do4 & I regularly tell my colleagues what I am doing \\
\hline \multirow{4}{*}{$\begin{array}{l}\text { Knowledge } \\
\text { collection }(\mathrm{Co})\end{array}$} & Co1 & When I need certain knowledge, I ask my colleagues about it \\
\hline & $\mathrm{Co} 2$ & I like to be informed of what my colleagues know \\
\hline & $\mathrm{Co} 3$ & I ask my colleagues about their abilities when I need to learn something \\
\hline & $\mathrm{Co} 4$ & $\begin{array}{l}\text { When one of my colleagues is good at something I ask him/her to teach me how } \\
\text { to do that thing }\end{array}$ \\
\hline \multirow{4}{*}{$\begin{array}{l}\text { Innovative work } \\
\text { behavior (IN01) }\end{array}$} & In1 & I create new ideas for improvements \\
\hline & In2 & I often search out new working methods, techniques, or instruments \\
\hline & In3 & My ideas generate original solutions to problems \\
\hline & $\operatorname{In} 4$ & I work actively to test new ideas \\
\hline
\end{tabular}


Appendix 2

\begin{tabular}{|c|c|c|c|}
\hline Factor & Item & Factor loading & Cronbach's Alpha \\
\hline \multirow{4}{*}{ Trust (Tru) } & Tru1 & 0.697 & \multirow{4}{*}{0.882} \\
\hline & Tru2 & 0.868 & \\
\hline & Tru3 & 0.794 & \\
\hline & Tru4 & 0.861 & \\
\hline \multirow{4}{*}{$\begin{array}{l}\text { Enjoyment in helping } \\
\text { others (En) }\end{array}$} & En1 & 0.796 & \multirow{4}{*}{0.885} \\
\hline & En2 & 0.915 & \\
\hline & En3 & 0.717 & \\
\hline & En4 & 0.864 & \\
\hline \multirow{4}{*}{$\begin{array}{l}\text { Knowledge self-efficacy } \\
\text { (Se) }\end{array}$} & Se1 & 0.735 & \multirow{4}{*}{0.837} \\
\hline & $\mathrm{Se} 2$ & 0.813 & \\
\hline & $\mathrm{Se} 3$ & 0.775 & \\
\hline & $\mathrm{Se} 4$ & 0.683 & \\
\hline \multirow{4}{*}{ Management support (Ma) } & Ma1 & 0.742 & \multirow{4}{*}{0.781} \\
\hline & Ma2 & 0.643 & \\
\hline & Ma3 & 0.777 & \\
\hline & Ma5 & 0.581 & \\
\hline \multirow{6}{*}{$\begin{array}{l}\text { Using information and } \\
\text { communication technology } \\
\text { (Te) }\end{array}$} & Te1 & 0.993 & \multirow{6}{*}{0.842} \\
\hline & $\mathrm{Te} 2$ & 0.973 & \\
\hline & Te3 & 0.956 & \\
\hline & $\mathrm{Te} 4$ & 0.933 & \\
\hline & Te5 & 0.937 & \\
\hline & Te6 & 0.989 & \\
\hline \multirow{4}{*}{ Knowledge donation (Do) } & Do1 & 0.939 & \multirow{4}{*}{0.790} \\
\hline & Do2 & 0.918 & \\
\hline & Do3 & 0.946 & \\
\hline & Do4 & 0.933 & \\
\hline \multirow{4}{*}{ Knowledge collection (Co) } & Co1 & 0.648 & \multirow{4}{*}{0.809} \\
\hline & $\mathrm{Co} 2$ & 0.944 & \\
\hline & Co3 & 0.713 & \\
\hline & $\mathrm{Co} 4$ & 0.581 & \\
\hline \multirow{4}{*}{$\begin{array}{l}\text { Innovative work behavior } \\
\text { (IN01) }\end{array}$} & In1 & 0.696 & \multirow{4}{*}{0.808} \\
\hline & $\operatorname{In} 2$ & 0.757 & \\
\hline & $\operatorname{In} 3$ & 0.737 & \\
\hline & In4 & 0.691 & \\
\hline
\end{tabular}

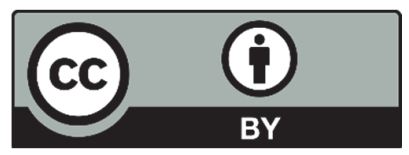

(C) 2019 by the authors; licensee Growing Science, Canada. This is an open access article distributed under the terms and conditions of the Creative Commons Attribution (CC-BY) license (http://creativecommons.org/licenses/by/4.0/). 